\title{
COLLECTIVE WORK AS AN INSPIRATION FOR LEGAL QUALIFICATION OF COMPUTER-GENERATED WORKS - COMPARATIVE ANALYSIS OF THE INSTITUTION FROM POLISH AND FRENCH COPYRIGHT LAW PERSPECTIVE
}

\author{
Michalina Kowala*
}

\begin{abstract}
The paper focuses on the question whether the institution of collective work could be used as an inspiration in order to regulate the legal situation of computer-generated works. Technological progress makes the creation of art by artificial intelligence with only minimal human participation an increasingly popular phenomenon. For this reason, world literature more and more often discusses how to legally qualify algorithmic creativity. An interesting idea, proposed in January 2020 by French Superior Council of Literary and Artistic Property is to regulate the issue alike the institution of a collective work. The study of the nature of computer-generated creativity on the example of the Endel musical start-up conducted in this paper will help to understand the complexity of the problem of algorithmic creativity. It will be also a valuable introduction to the analysis of the institution of collective work in Polish and French law. This comparative study will be important in the context of assessing the French proposals for the legal qualification of algorithmic creativity and examining to what extent the model of the collective work can be applied to computer-generated works in Polish copyright law.
\end{abstract}

Keywords: Collective work, Artificial Intelligence, copyright, French proposals

* Michalina Kowala, M.A., PhD candidate at the Faculty of Law and Administration, Adam Mickiewicz University Poznań, Student of College of Europe in Bruges, Belgium; correspondence address: Al. Niepodległości 53, 61-714 Poznań, Poland; e-mail: michalina.kowala@coleurope.eu; https://orcid.org/0000-0002-9149-6747. 


\section{INTRODUCTION}

It is estimated that there is a $50 \%$ chance that in 2040 artificial intelligence ${ }^{1}$ will equal human intelligence, and the probability will rise to $90 \%$ in $2075^{2}$. Nowadays, AI enters our everyday life. This technology is also increasingly used in art. Neuron networks as a mathematical representation of the human nervous system ${ }^{3}$ can act like a human being and learn to paint, write or compose. Moreover, with the emergence of new artistic initiatives, the way of perceiving the role of AI, previously defined as a tool for creating a work, and today as an independent creator, is changing. This new trend and greater independence of AI appearing as ability to make creative, difficult to predict and non-obvious choices about the elements of the work contributes to the uprising of practical legal problems.

There is currently a lively discussion on whether it is necessary to grant legal protection to computer-generated works and if so, what kind of protection will be the most appropriate. According to the Polish Copyright $\mathrm{Act}^{4}$, moral and economic rights can be assigned exclusively to human beings. Nevertheless, it should be repeated after D. Flisak, who rightly notices that in the content of Art. 1 of the Act, the creativity is not expressis verbis attributed to human and there is no clear indication that the subject of copyright must only be an expression of the creative activity of a human being ${ }^{5}$. Since the requirement of human creation in the Polish Copyright Act is not literally indicated, it is worth considering

1 Hereinafter: AI.

2 Vincent C. Müller and Nick Bostrom, "Future Progress in Artificial Intelligence: A Survey of Expert Opinion," in Fundamental Issues of Artificial Intelligence, ed. Vincent C. Müller (Berlin: Synthese Library, Springer, 2014), 14, accessed February 20, 2021, https://www.nickbostrom.com/papers/survey.pdf.

3 Anna Kasperska, "Problemy zastosowania sztucznych sieci neuronalnych w praktyce prawniczej," Przeglad Prawa Publicznego, no. 11 (2017): 25.

4 Act on copyright and related rights of 4 February 1994, Journal of Laws 2019, No. 1231 as amended. English version available on the WIPO website: https://www.wipo.int/ edocs/lexdocs/laws/en/pl/pl010en.pdf, accessed December 11, 2019, hereinafter Polish Copyright Act.

5 Damian Flisak, "Czy robotowi przysługują prawa autorskie? Wywiad z dr Damianem Flisakiem," interview by Magdalena Miernik, 2017, accessed August 27, 2020, 
whether AI's work could be treated as the subject of copyright. At this point, for the purposes of further analysis, it should be assumed that computer-generated art meets the premises of originality ${ }^{6}$, individuality $^{7}$ and fixation which will allow us to proceed the consideration who should be granted copyright due to its involvement in the process of making of the work.

The recent report prepared by the French Superior Council of Literary and Artistic Property ${ }^{8}$ introduced a new proposal concerning legal protection of AI's works, considered as possible modification of the Intellectual Property Code in France. By using the model of collective work which nature largely resembles the specificity of the process of AI's works creation, the balance between artistic and economic dimension could be reached. Importantly, the use of this construction could simplify and clarify from the legal point of view the complexity of the creative process and diversified involvement of many people at various stages of AI work's creation.

The aim of this article is to present a new proposal concerning legal qualification of AI's works based on collective work construction introduced in France and discuss its possible application in the Polish copyright

https://lookreatywni.pl/baza-wiedzy/czy-sztuczna-inteligencja-zmieni-prawo-autorskie -wywiad-z-dr-damianem-flisakiem/.

6 The results of machines' work are more and more often qualified as creative and innovative as well as exceeding the skills and abilities of machines' creators. See: Jared Vasconcellos Grubow, "O.K. Computer: The Devolution of Human Creativity and Granting Musical Copyrights to Artificially Intelligent Joint Authors," Cardozo Law Reviev 40, no. 1 (2018): 404-405; James Wagner, "Rise of the Artificial Intelligence Author," Advocate 75, no. 4 (2017): 531.

7 Due to technological development, the criterion of individuality can be considered as problematic in the context of potential acceptance of the non-human beings 'creativity. Many scholars point out that works created by AI do not reflect the personality of its creator because the creator in this case is a machine. However, the individual character of the work can be identified through the prism of its distinctness from the others works. See: John Pavlus, "Clever Machines Learn How to Be Curious," 2017, accessed December 13, 2019, https://www.quantamagazine.org/clever-machines-learn-how-to-be-curious-20170919/.

8 "Mission Intelligence Artificielle Et Culture," Conseil Supérieur De La Propriété Littéraire Et Artistique, 2020, point 2.2.1., accessed May 08, 2020, https://www.wipo.int/ export/sites/www/about-ip/en/artificial_intelligence/call_for_comments/pdf/ms_france_ cspla_fr.pdf. 
regime. Part I of this article will provide a brief presentation of functioning of one start-up based on autonomous AI from the legal point of view in order to indicate the properties which characterize the process of creating computer-generated works. In part II and III an analysis of collective work's construction in Polish and French copyright law will be conducted. The comparative study will allow to consider the structure of this institution and check similarities and differences in the way it is regulated in Polish and French copyright acts. Lastly, in part IV the proposals prepared by French Superior Council of Literary and Artistic Property will be evaluated. The main purpose of this final part is to answer the question to what extent the structure of a collective work is appropriate for regulating the issue of AI works and how the proposals made in French Copyright law could be translated in Polish Copyright law - the lege ferenda postulates will be formulated.

\section{THE NATURE OF COMPUTER-GENERATED ART}

Technological changes, minimizing the role of humans in generating art by AI and complexity of this process is reflected in the German start-up Endel, which in 2019 released an application for creating music by AI based on individual user data such as biometric data - pulse, conditions of weather, time of day and location. Using this information, the AI generates reactive, personalized "soundscapes" "which help to focus or relax. The German start-up attracted the attention of Warner Music Group - an American international entertainment and music label. This interest resulted in a multi-billion dollar ${ }^{10}$ contract to record a total of 20 Warner Music albums. The cooperation is described by the developers of the application as a breakthrough, because the generation of songs took place without human intervention. Indeed, humans did not participate in the act of generating music, the machine did

9 "Endel to release 20 algorithm- powered albums to help you sleep, focus \& relax," accessed March 27, 2020, https://endel.io/presskit/Endel-PressRelease-20MusicAlbums.pdf.

10 Hayleigh Bosher, "Warner Music signs distribution deal with AI generated music app Endel,” 2019, accessed March 27, 2020, http://ipkitten.blogspot.com/2019/03/ warner-music-signs-distribution-deal.html. 
the creative task - "Dmitry Evgrafov, Endel's composer and head of sound design, says all 600 tracks were made with a click of a button." ${ }^{11}$ However, it should be specified that humans had been involved at every stage of process not participating in the last, final act of music creation ${ }^{12}$. It's worth to note that without his/her involvement this act of music composition by AI would not be possible. The presentation of human participation should begin with indicating that a given machine, in order to compose, must be constructed and in that purpose the involvement of engineers ${ }^{13}$ and technology specialists is necessary ${ }^{14}$. Secondly, AI must be properly programmed - in that respect the work of programmers needs to be highlighted. In order to obtain the appropriate results, data training is carried out, after an introduction of specific data related to expected final effects. At this stage the important role is played by data trainers who oversee the training process and correct errors in recognizing and learning data ${ }^{15}$. In the case of Endel's compositions human involvement also consisted of chopping up the audio, mastering it for streaming as well as writing the track titles ${ }^{16}$.

11 Dani Deahl, "Warner Music signed an algorithm to a recorded deal- what happens next?," 2019, accessed March 27, 2020, https://www.theverge.com/2019/3/27/18283084/ warner-music-algorithm-signed-ambient-music-endel.

12 Bosher, "Warner Music signs," accessed March 27, 2020, http://ipkitten.blogspot.com/2019/03/warner-music-signs-distribution-deal.html, "The Endel-Warner deal is a step forward in that there are no human collaborators in the generation of the new sounds. Nevertheless, a human - aside from obviously creating the AI - also had to, input sounds and data into Endel. Interestingly Stavisky ( CEO, founder of Endel) describes the work as being "generated based on different combinations of inputs" rather than created. Some of these inputs, or instrumental stems, were created by Endel's co-founder and sound designer Dmitry Evgrafov. Each sound is then allocated metadata according to certain parameters which the app can read and use to generate a soundscape. So, whilst it might seem that the sounds are created with a click of a button, Stavisky explained that it took "1.5 years of work developing our algorithm and creating and tagging the stems".

13 Amy X. Wang, "Warner Music Group Signs an Algorithm to a Record Deal," 2019, accessed August 31, 2020, https:/www.rollingstone.com/pro/news/warner-music -group-endel-algorithm-record-deal-811327.

14 Jim Hughes, “The Key Roles of AI Engineers," 2019, accessed August 27, 2020, https://engineeringmanagementinstitute.org/key-roles-ai-engineers.

15 Kasperska, "Problemy zastosowania sztucznych sieci," 25-27.

16 Deahl, "Warner Music signed an algorithm," accessed March 27, 2020, https://www .theverge.com/2019/3/27/18283084/warner-music-algorithm-signed-ambient-music-endel. 
The complexity of the creative process and the participation of so many people who have a greater or lesser influence on the final result requires appropriate financial outlays, proper preparation, supervision and organization. Moreover, from the legal point of view, appropriate agreements should be concluded with the authors of individual elements, such as computer programs or databases, regarding the possibility of using them on the basis of a license or the acquisition of economic rights. Therefore, a key role is played by producers who organise the project and finance it, acquire ownership or buy the licenses to use the software, databases as well as lyrics or titles for songs creates by AI and thus obtain the copyright to these items. The final effect does not consist of the elements like software, or training data set but is the result of their functioning. However, the use of them is necessary for the work to be created. Consequently, when characterizing the nature of computer-generated art, it should be pointed out that human involvement is essential for the work to be created. However, in most cases this involvement cannot be qualified as creative and this is why the attribution of authorship to works produced by AI to humans cannot be considered. Nonetheless, as stated, human contribution to the creation of the work is essential, the example of the producer's involvement which rather than creative, should be qualified as organisational could be given. The use of deep learning technology, which determines the unpredictability of the final result, contributes to even greater independence of $\mathrm{AI}$ in creating due to the complexity of the machine's neural networks ${ }^{17}$. However, the producer makes an important logistic, control and financial contribution and consequently has considerable impact on the creative process which is distinguished by multiple stages and the involvement of many people, between whom there is no agreement regarding the final result of the creative process. Therefore, copyright law faces the challenge of how to qualify this human activity, which is not based on creative but on financial, technical and organizational commitment. In the literature, due to these justifications, it is proposed to introduce a new related law or

17 Shlomit Yanisky-Ravid, "Generating Rembrandt: Artificial Intelligence, Copyright and Accountability in the 3A Era: The Human-like Authors are already here: A New Model," Michigan State Law Review no. 4 (2017): 686. 
sui generis protection ${ }^{18}$ which would well reflect the role of the producer. These proposals, however, also have many opponents who point that an excessive focus on the economic aspects of creativity and insufficient protection of artistic values as well as potential promotion of mass production of computer-generated works may devalue human creativity and question the foundations of copyright ${ }^{19}$. For this reason, the project proposed in France, which can be interpreted as a golden mean between the economic and artistic implications of the legal qualification of AI products should be presented.

\section{CONSTRUCTION OF COLLECTIVE WORK IN POLISH COPYRIGHT LAW FROM THE COMPUTER-GENERATED ART PERSPECTIVE}

According to article 11 of the Polish Copyright Act "The producer or publisher shall have the author's economic rights in a collective work and in particular the rights in encyclopedias or periodical publications, and the authors shall have economic rights in their specific parts which may exist independently. It shall be presumed that the producer or publisher have the right to the title." Firstly, it is necessary to indicate how the collective work is defined and what are its characteristics. The essence of this construction is the combination of many creative contributions from different people who are not bound by any agreement. Each of them creates a separate part, independently of others involved in the creation process. All these elements will contribute to the final effect. The key role is played by the producer or

18 See: Jane C. Ginsburg, “The Author's Place in the Future of Copyright,” Proceedings of the American Philosophical Society 153, no. 2 (2009): 147-159; Damian Flisak and Ireneusz Matusiak, "Ab homine Auctore Ad Robotum Auctorum," in Opus auctorem laudat. Księga jubileuszowa dedykowana Profesor Monice Czajkowskiej-Dąbrowskiej, ed. Krystyna Szczepanowska-Kozłowska, Ireneusz Matusiak, and Łukasz Żelechowski (Warsaw: Wolters Kluwer, 2019).

19 Eduard Treppoz et al., "Droit d'auteur sur les œuvres générées artificiellement," AIPPI, Question 15, accessed August 31, 2020, https://www.aippi.fr/upload/2019\%20 Londres/DROIT_DAUTEUR_-_Rapport_definitif.pdf. 
publisher who initiates and organizes the work ${ }^{20}$ which is the sum of separate parts that may or may not be the subject of copyright. If so, these rights remain with the authors of separate parties, despite their inclusion in a collective work, unless otherwise agreed between the producer / publisher and the creator which is confirmed in the judgement of Court of Appeal in Warsaw from 1999: The publisher acquires the copyrights to the individual parts in a derivative way, by concluding contracts with the authors of the parts ${ }^{21}$.

Comparing the observations already made to algorithmic creativity, it should be stated that the individual elements determining the shape of the final work are basically created independently by different people, not bound by the agreement. The creative process can progress thanks to the producer, responsible for combining the effects of their work together and handing over the elements already produced for further development. In the case of AI works, the issue is different, although there is no simple combination of elements- it is not necessary to combine all the components into a uniform whole. In the case of machine activity, it would rather take the form of a sequence of elements the use of which would contribute to the creation of the final work. Each of these elements, from the algorithm, through software, the use of machine learning techniques and data training to the generation function, would be necessary for the creation of a work, and a fundamental role in the context of the selection of these elements and providing financial and organizational facilities would be played by the producer/publisher.

Referring to the already cited article 11 collective works are encyclopedias and periodical publications but it should be noted that this is not an exhaustive list, but an example which gives an overview of the nature of this institution. More important than the qualification of a work is the confirmation of presence of a person acting like producer and involved in the creating process of a multi-component work ${ }^{22}$. Therefore, his role, as

20 Appellate Court in Warsaw, Judgement of 26 January1995, Ref. No. I ACr 1037/94, LEX no. 535044.

21 Appellate Court in Warsaw, Judgement of 18 November 1999, Ref. No. I ACa 792/99, LEX no. 535049.

22 Damian Flisak, "Prawo autorskie i prawa pokrewne. Komentarz do art. 11," in Prawo autorskie i prawa pokrewne. Komentarz, ed. Damian Flisak (Warsaw: Wolters Kluwer - LEX, 2015), argument 7. 
well as the duties and powers should be analyzed. In article 11 of the Polish Copyright Act there is no definition of producer/publisher. It is just indicated that he has the economic right to collective work as well as the right to the title. However, it is necessary to answer the question whether the producer is a natural person, as it is assumed in relation to the author, pursuant to Article $8^{23}$, or is it both a natural and legal person. According to article 15 of the Polish Copyright Act, the producer is the one whose surname or business name is disclosed on the objects on which the work was fixed what proves that it can be not only a natural person, but also a legal person pursuant to $\$ 1$ of article $43^{5}$ of Polish Civil Code ${ }^{24}$.

The producer performs an initiating and ordering function - he is involved in combining separate creative contribution ${ }^{25}$. His main task is therefore to mediate in the process of creating a work consisting of many components. He has a "multifaceted" 26 role based not only on involvement in the preparation of the work in the financial and organizational dimension, but also in supporting creative works, bearing risk and responsibility for its results ${ }^{27}$. When comparing the scope of the producer's tasks based on the regulations from Article 11 to the example of creating music by $\mathrm{AI}$ as part of the Endel start-up, it should be stated that these tasks are similar. In the case of the Endel start-up, producers from Warner Music were obliged to conclude contracts for the purchase of software, lyrics or titles for individual songs. They decided about the final shape of the composi-

${ }^{23}$ Article 8 of Polish Copyright Law: 1. The owner of the copyright shall be the author unless this Act states otherwise. 2. It shall be presumed that the author is the person whose name has been indicated as the author on copies of the work or whose authorship has been announced to the public in any other manner in connection with the dissemination of the work. 3. In order to exercise his/her copyright the author, as long as he/she does not disclose his/her authorship, shall be represented by the producer or the publisher and in the absence thereof - by the competent collective management organization.

24 The civil code, Act of 23 April 1964, Journal of Laws 2019, No. 1145,495; 2020 No. 875, English version: https://supertrans2014.files.wordpress.com/2014/06/the-civilcode.pdf, accessed August 27, 2020.

25 Appellate Court in Warsaw, Judgement of 26 January 1995, Ref. No. I ACr 1037/94, LEX no.535044.

26 Flisak, "Ustawa o prawie autorskim," argument 1.

27 Polish Supreme Court, Judgement of 15 November 2002, Ref. No. II CKN 1289/00, reported in: OSNC Journal 2004, no. 3, pos. 44. 
tions, supervised the course of the creative process and made appropriate financial outlays ${ }^{28}$.

The authors of individual works that make up the collective, according to Polish Copyright law work retain the copyrights, including economic rights, to their works, but it is also possible to transfer them to the producer or publisher by means of an appropriate agreement. The publisher /producer acquires ex lege copyrights to the entirety of a collective work, which means to the selection, ordering and linking of work's individual parts. Consequently, the important task is to select the material previously prepared and combine it in a certain way. The essence of the collective work's construction is the creation on the publisher/producer's side of the right to exploit the collection of works as a whole. ${ }^{29} \mathrm{He}$ may dispose of the entire work, but he has no right to decide on the legal status of individual parts of it, if a specific part is protected by copyright and economic rights have not been transferred to him. When it comes to shaping the legal situation of the producer compared to the authors of individual component parts, it is necessary to conclude the employment contracts or license agreements with them that will allow the use of a specific element in a collective work.

The producer or publisher acquires the economic rights to the collective work at the time it is fixed, and his relation to the resulting product can be compared to the author's power over his work ${ }^{30}$. It should be assumed that granting a publisher/ producer of economic copyrights ex lege results, firstly, from his contribution to the preparation of a collective work, which is not only financial and organizational, but often has the character of his own creative work; secondly - from the risk and responsibility ${ }^{31}$; thirdly -

28 See: Bosher, "Warner Music signs," accessed March 27, 2020, http://ipkitten.blogspot .com/2019/03/warner-music-signs-distribution-deal.html.

29 Wojciech Machała, "Prawo autorskie i prawa pokrewne. Komentarz do art. 11," in Prawo autorskie i prawa pokrewne. Komentarz, ed. Rafał Sarbiński, and Wojciech Machała (Warsaw: Wolters Kluwer - LEX, 2019), argument 5.

30 Dorota Sokołowska, "Utwory zbiorowe w prawie autorskim," Zeszyty Naukowe Uniwersytetu Jagiellońskiego. Prace z Prawa Wtasności Intelektualnej, no. 1 (2001): 95.

31 Polish Supreme Court, Judgement of 15 November 2002, Ref. No. II CKN 1289/00, reported in: OSNC Journal 2004, no 3, pos. 44. 
from practical reasons related to difficulties in identifying the co-authors of the collective work ${ }^{32}$.

\section{CONSTRUCTION OF COLLECTIVE WORK IN FRENCH COPYRIGHT LAW - A COMAPARATIVE ANALYSIS}

The aim of this part of the article is to present in a comparative way the French regulations of a collective work in relation to Polish regulations. The characteristics of the collective work, the role of the producer / publisher as well as the rights of the authors of the individual parts that make up the collective work will be discussed. According to article L113-2 of the French Intellectual Property Code ${ }^{33}$ : "Collective work shall mean a work created at the initiative of a natural or legal person who edits it, publishes it and discloses it under his direction and name and in which the personal contributions of the various authors who participated in its production are merged in the overall work for which they were conceived, without it being possible to attribute to each author a separate right in the work as created" and according to article L113-5 "A collective work shall be the property, unless proved otherwise, of the natural or legal person under whose name it has been disclosed. The author's rights shall vest in such person." A collective work is a combination of multiple contributions from different authors, described as a plural work in which the individual contributions merge into the whole in view from which they are made ${ }^{34}$. The combination made on the initiative of a natural or legal person who publishes, edits and discloses it under his name. Contrary to Polish law, the content of the article does not provide examples of collective works, which allows the presumption that the scope of this provision may be greater and cover more types of works. However, it should be recalled that

32 Marlena Jankowska, "Ustawa o prawie autorskim i prawach pokrewnych. Komentarz do art. 11," in Ustawa o prawie autorskim i prawach pokrewnych. Komentarz, ed. Piotr Ślęzak (Warsaw: C.H. Beck - Legalis, 2017).

33 English version available: https://www.wipo.int/edocs/lexdocs/laws/en/fr/fr467en.pdf, accessed August 28, 2020.

34 André R. Bertrand, "Auteur et titulaires des droits d'auteur," in Droit d'auteur, ed. André R. Bertrand (Paris: Dalloz action, 2010), 204. 
the enumeration in Article 11 of the Polish Copyright Act is only exemplary and does not constitute any limitation for qualifying as a collective work a work other than an encyclopedia and a periodical publication.

It is worth to point out that contrary to the Polish Copyright Act the term producer, in the French Intellectual Property Code is not literally used in the case of collective work. In articles L113-2 and L113-5 the term natural or legal person is employed. In doctrine, in that respect, the terms like initiator, producer, editor and advertiser are also used interchangeably $^{35}$ which proves that the semantic scope of this article, despite the lack of direct use of the term the producer/publisher refers to the type of tasks performed by him.

Commitment should be assessed firstly from the perspective of initiating the work. According to article L113-2 the natural or legal person initiates the creation of the collective work which means that this person should contribute to the commencement of the works, supervise their execution, ensure compliance of the results achieved with the intended effect, support the project in terms of financial and organizational aspects ${ }^{36}$, but also combine individual elements and introduce appropriate amendments justified by the harmonization of the entire piece. ${ }^{37}$ Moreover, a natural or legal person is responsible for editing, publishing and disclosing the work under his/her direction and name. Importantly, the person ensures proper reproduction of the work and its delivery to the public. The authors of individual elements have creative freedom but within the limits set by the initiator ${ }^{38}$ who controls the process of creating the work ${ }^{39}$ and this is the reason why collective work is described by many scholars as "py-

35 Bertrand, "Auteur et titulaires," 206.

36 Bertrand, "Auteur et titulaires," 206.

37 The Court of Cassation, Civil Chamber 1, Judgement of 16 December 1986, Ref. No. 85-10.838., Published in Bulletin.

38 Bertrand, "Auteur et titulaires," 208.

39 Although the obligation to exercise control over the process of creating a work is not directly expressed in the legal text, such a requirement has been formulated by the doctrine and jurisprudence. Jean Cedras, "La qualification des oeuvres collectives dans la jurisprudence actuelle," Revue juridique de l'Ouest, no. 2 (1995): 140. 
ramidal" or "hierarchical" 40 . It should be noted that French construction is more focused on the producer's task - pointing out that the producer comes up with the initiative to create a work and later publishes, edits and discloses it. In Polish law, the role of a producer in relation to a collective work is not defined in the Copyright Act. It is necessary to refer to the literature to find out that, similarly to French law, a producer is a person actively involved in the process of preparing a work site and bearing financial and organizational risk related to production and distribution ${ }^{41}$. According to J. Barta and R. Markiewicz, it is the producer's responsibility to indicate the conceptual framework, organize, coordinate and support in the financial aspect the intellectual work of the team ${ }^{42}$. As a consequence, the scope of the producer's tasks, although indicated otherwise, looks similar. In France, both in the doctrine and jurisprudence, enumeration of a producer's tasks is treated as an example, because many collective works are not subject to, for example, editorial activities. In this way, many works meeting all the criteria for a collective work but involving a different activity of the producer as collective works could not be qualified ${ }^{43}$. For this reason, the lack of enumeration of the producer's competences in Polish legislation and outlining their tasks in the doctrine and jurisprudence seems to be more justified. This observation is interesting in the context of algorithmic creativity. It may happen that the producer, although initiating the process, will not perform the editorial activity, simply combining individual elements that will later be disclosed and published.

40 Nathalie Cazeau, "Le titulaire des droits d'exploitation sur une œuvre collective peut -il librement la faire évoluer ?," 2007, accessed August 28, 2020, https://www.village -justice.com/articles/titulaire-droits-exploitation-oeuvre-collective,3008.html; Cedras, "La qualification," 140.

41 Marlena Jankowska, "Ustawa o prawie autorskim i prawach pokrewnych. Komentarz do art. 15," in Ustawa o prawie autorskim i prawach pokrewnych. Komentarz, ed. Piotr Ślęzak (Warsaw: C.H. Beck - Legalis, 2017), argument 1.

42 Janusz Barta and Ryszard Markiewicz, "Prawo autorskie i prawa pokrewne. Komentarz do art.11," in Ustawa o prawie autorskim i prawach pokrewnych. Komentarz ed. Janusz Barta and Ryszard Markiewicz (Warsaw: Wolters Kluwer, 2011), 140.

43 André Lucas, Henri-Jacques Lucas and Agnès Lucas-Schloetter, "Traité de la propriété littéraire et artistique, » 4th ed., (Paris: Lexis Nexis, 2012), supra note 73,215. 
The Polish legislator decides to grant producer economic rights to the entire work. According to article L113-5 collective work becomes the property of the natural or legal person under whose name it has been disclosed. The author's rights shall vest in such person. The producer is granted the copyrights because of his/her intellectual and material involvement in the creation of the work. However, the issue of the adequacy of the wording contained in this French provision is widely discussed. As the author's rights shall be vested in natural or legal persons, the question whether the legal person could be considered as author within French Intellectual Property Code meaning should be asked. According to the French conception of copyright, only a natural person can be considered as the author because of his/her capacities to create within copyright meaning ${ }^{44}$. Therefore, granting of moral and economic rights to the legal person who initiates the collective work and coordinates the work and the subsequent publication of its effects should be considered as a legal fiction. ${ }^{45}$ Moreover, the French conception of moral person as copyright owner in the collective work case should not be confused with the notion of author intended for natural persons ${ }^{46}$. It should be unequivocally stated that the wording of the Polish article relating to the collective work is more precise and dispels any potential doubts by granting economic rights to the work to the producer or publisher and not granting moral rights, which are always reserved for the author of the work (human being).

In France, the copyright to the entire work and, in the case of concluding the relevant agreements, the economic rights to individual parts are transferred to the producer. At the same time the authors of individual parts retain moral rights to them. ${ }^{47}$ The main reason why they cannot take advantage of an undivided right to the work produced is lack of the cooperation between them in the creation process and the leading role of

44 The Court of Cassation, Civil Chamber 1, Judgement of 15 January 2015, Ref. No. 13-23.566, Published in Bulletin.

45 Cedras, "La qualification," 136.

46 Cedras, "La qualification," 136.

47 The Court of Cassation, Civil Chamber 1, Judgement of 15 April 1986, Ref. No. 84-12.008, Published in Bulletin. 
producer who takes responsibility for the entire work and under whose name the work is published. ${ }^{48}$

In order to sum up, it should be stated that the concept of a collective work is similar in both legislations and its main assumptions are the same, considering the nature of the collective work, the role of the producer and the rights of the authors of individual parts. There are some differences when it comes to determining the types of collective works in Polish law and the tasks of the producer in the case of French law, however, it is necessary to specify that the analysis of doctrine and jurisprudence leads to similar conclusions in these contexts, both in Polish and French law. The only significant difference is dissimilar wording regarding the granting of copyright to the producer of the collective work. French law allows the creation of a legal fiction and the author's rights are vested in moral or legal person, which leads to the acquisition of moral and economic rights. Polish law is limited to granting only economic rights to a work to the producer/ publisher and it must be admitted that this is a better solution. Moreover, it should be stated that the structure of a collective work and the manner of its regulation in both jurisdictions correspond to the nature of the computer-generated works.

\section{COMPUTER-GENERATED WORKS AS COLLECTIVE WORKS ACCORDING TO FRENCH COPYRIGHT LAW PROPOSALS - CAUSES, PREMISES AND CONSEQUENCES}

According to the report prepared by the Superior Council of Literary and Artistic Property in January 2020, the model of the collective work could be applied to the computer-generated works. There are several reasons for this concept. Firstly, this construction presents a more economical approach to copyright, less focused on the creator himself but still rooted in copyright grounds. Secondly, the collective work is derogatory from the classic rules of ownership, since the rights arise, independently of any transfer, in favor of the producer who, in a vertical creative process,

48 The Court of Cassation, Civil Chamber 1, Judgement of 18 October 1994, Ref. No. 92-17.770, Published in Bulletin. 
directs the creation and publishes it under his name ${ }^{49}$. The structure of the collective work is close to the specificity of algorithmic creativity due to the complexity of the process of creating the work, the involvement of many people and the leading role of the producer. Therefore, in the French report "Mission Intelligence Artificielle Et Culture" it is proposed to add a fourth paragraph to Article L. 113-2 of the French Intellectual Property Code in order to define the work created by AI as "the creation generated by an artificial intelligence and to the realization of which there was no human being contribution". Indeed, such provision should be introduced with the aim to indicate the assumptions of the new institution. Since humans do not take part in the realization of the work, there is therefore no one who could be considered as the author ${ }^{50}$. If, however, it is assumed that such a work should be protected, it is necessary to consider who should be granted these rights. In this regard it is proposed to amend article L.113-5 and the new content would be as follows: "The collective work and the work generated by an AI are, unless proven otherwise, the property of the natural or legal person under whose name they are disclosed. This person is vested with copyright" ${ }^{\prime \prime}$.

This proposal needs some observations to be made. Firstly, the definition of a computer-generated work is not based on the definition of a collective work, even though the proposal of article 113-5 treats both institutions in the same way by granting copyright to natural or legal person under whose name they are disclosed. This may introduce some misunderstanding of the institution of a computer-generated work and questions as to whether these institutions are similar to each other or not, since the definition of computer-generated works does not mention the similarity to the structure of a collective work, and later both these institutions in terms of producer rights are treated the same. On the other hand, it should be noted that despite the similarities between a collective work and

49 "Mission Intelligence Artificielle Et Culture," p. 2.2.1.

50 In France, there is a humanistic concept of copyright, which treats the work as the fruit of human creativity, the source of which is the human intellect. In that respect just moral person could be treated as author. See: The Court of Cassation, Civil Chamber 1, Judgement of 15 January 2015, Ref. No. 13-23.566, Published in Bulletin; "Mission Intelligence Artificielle Et Culture," p. 2.1.2.

51 “Mission Intelligence Artificielle Et Culture," p. 2.2.1. 
a machine-generated work which were pointed out in the previous part of this article, the latter type, due to the progressing automation, is less and less dependent on the creative involvement of human beings. It may also be that the programmer will prepare the software and only this will be enough for the machine to create a work. So, the creation of the work would not consist of many stages but one significant that would be supervised by a natural/legal person. In fact, therefore, the role of the person under whose name the publication will take place will be important, but due to the increasing autonomy of machines, this process does not have to be as multi-stage as it is in the case of a collective work. Thus, an overly casuistic definition and direct comparison to a collective work would not be advisable. It is justified to resign from enumerating examples of computer-generated works and tasks of a natural or legal person due to the complex and difficult to predict process of creating a computer-generated work and its various types.

Moreover, there is no indication that the copyright is acquired by the producer, but by a natural or legal person under whose name the work is published as it was in the case of a collective work. It should be pointed out that it is the right move. The wording used in the report is more comprehensive and universal - in many cases that person will act as producer but it may happen that a person who does not demonstrate activities appropriate for the producer will be granted the copyright to the work. Nevertheless, it must not be forgotten that regarding the role of a natural / legal person in the context of collective work, the description of the activity and lexical field used in the doctrine and jurisprudence indicate that such a person could be treated as producer / publisher. Therefore, it should be considered whether, in relation to computer-generated works, it would be possible to consider the term natural or legal person under whose name the work is published in a broader context, not referring only to the role of the producer/publisher. If so, we could consider the involvement of users who, on the basis of a license or purchase, acquire the copyright to a specific version of artificial intelligence and use it to produce specific works that later can be published under their name.

When asking the question whether the regulation of the legal situation of computer-generated works in the manner presented in France may be appropriate, it should be answered that the proposed changes adequate- 
ly capture the nature of algorithmic creativity, and the lack of excessive casuistry prepares the law for further technological changes in culture. The proposed definition properly separates works created by machines with a significant creative participation of humans from those created without human involvement. The role of the person under whose name the work could be published is also rightly noticed, assuming that she/he makes a significant contribution to the creation of the work, not necessarily in a creative way, and should be granted copyright.

When trying to apply the French propositions to the Polish juridical framework, it should be pointed out that the definition of the computer-generated work could be introduced following the definition proposed in the French report which a little casuistic nature allows for the preparation of the law for further technological changes in art. In the same or a new article, as proposed in the French version, it should be decided who could be granted the copyright for the work. At the same time, it must be considered whether to do so in conjunction with an already existing regulation on collective works or separately. In the case of Polish law, the provisions concerning this institution are contained in one article, while in the French they are divided into two. Perhaps, due to inspiration only by the regulation of a collective work, provisions on computer-generated works in Poland should be included in a separate article. When it comes to acquisition of copyrights it's worth to note that the statement made in the French proposal that a natural or legal person is vested with copyrights to the work could not be applied in Poland and we should lean toward the current wording of article 11 of the Polish Copyright Act and apply similar solutions, clearly specifying that such a person may acquire only economic rights to the work. Otherwise, it would conflict with the fundamental principles of copyright law as the moral rights are reserved for natural persons and result from their creative engagement. ${ }^{52}$

52 Moral rights can be acquired only be a human being - a natural person - the creator of the work. As S. Ritterman noted: The fiction of the emergence of moral rights for the benefit of people not related to the work by a personal bond, seems to me both theoretically and practically unacceptable" See: Stefan Ritterman, Komentarz do ustawy o prawie autorskim (Cracow: W.L. Anczyca i Spółki, 1937), 170. 


\section{CONCLUSIONS}

The use of $\mathrm{AI}$ in art is becoming more and more popular. In world literature it is emphasized that due to technological progress and through the prism of the ability to learn independently and self-development of computer programs ${ }^{53}$, the role of humans in the creative process carried out by $\mathrm{AI}$ is decreasing and over time will become minimal ${ }^{54}$. Computer-generated works are often difficult to distinguish from those created by humans, and the process of their creation is often associated with substantial investments. Consequently, they should be granted copyright protection while not forgetting about the economic dimension. In that respect the concept proposed by the French Superior Council of Literary and Artistic Property could be considered. Firstly, the inspiration of collective work provision is a new solution and an answer to divided opinions about the granting of copyright to programmers or users. It does not contradict the foundations of copyright law - it does not assign copyright to a machine or seek creative human involvement. It considers his/her organizational commitment, financial outlays, control activities and the fact that the work is published under a given name. When analyzing what the protection of computer-generated works based on the structure of a collective work could bring, it should be emphasized that it is a combination of protection of the artistic values of works with economic aspects of creation. Copyright law in many cases focuses on the person of the creator and not on the subject of copyright ${ }^{55}$. On the other hand, related rights or the sui generis system puts a lot of emphasis on the economic aspects of $\mathrm{art}^{56}$, often ignoring the care of artistic context. For this reason, the construction of a collective work through the prism of algorithmic creativity is a combination of both of these directions. Importantly, it highlights the role of the person under whose name the work would be published

53 Magdalena Kubasiewicz, "Czym jest machine learning - technologia, która rewolucjonizuje świat?,” 2020, accessed March 20, 2020, https://www.intellect.pl/blog/machine -learning-co-to/?PageSpeed=noscript.

54 Robert C. Denicola, "Ex Machina: Copyright Protection for computer-generated works," Rutgers University Law Review 69 (2016): 269.

55 "Mission Intelligence Artificielle Et Culture," p. 2.1.2

56 Eduard Treppoz et al. "Droit d'auteur sur les œuvres,". 
and who would show commitment to the creation of a work that can be compared to the role of a producer in a collective work. In this regard the qualification inspired by the regulations of a collective work will note technological changes in the arts and will provide adequate protection for computer-generated works. It would be worthwhile for the Polish legislator, considering the issues of protecting algorithmic creativity, to take a closer look at the French proposals.

\section{REFERENCES}

Barta, Janusz, and Ryszard Markiewicz, ed. Prawo autorskie i prawa pokrewne. Komentarz. Warsaw: Wolters Kluwer, 2011.

Bertrand, André R. "Auteur et titulaires des droits d'auteur." In Droit d'auteur, edited by André R. Bertrand, 179-214. Paris: Dalloz action, 2010.

Bertrand, André R. "Auteur et titulaires des droits d'auteur." In Droit d'auteur, edited by André R. Bertrand, 735-757. Paris: Dalloz action, 2010.

Bosher, Hayleigh. "Warner Music signs distribution deal with AI generated music app Endel.” 2019. Accessed March 27, 2020. https://ipkitten.blogspot. com/2019/03/warner-music-signs-distribution-deal.html.

Cedras, Jean. "La qualification des oeuvres collectives dans la jurisprudence actuelle." Revue juridique de l'Ouest, no. 2 (1995): 133-147.

Cazeau, Nathalie. "Le titulaire des droits d'exploitation sur une œuvre collective peut - il librement la faire évoluer ?." 2007. Accessed August 28, 2020. https:// www.village-justice.com/articles/titulaire-droits-exploitation-oeuvre-collective,3008.html.

Deahl, Dani. "Warner Music signed an algorithm to a recorded deal- what happens next?." 2019. Accessed March 27, 2020. https://www.theverge. com/2019/3/27/18283084/warner-music-algorithm-signed-ambient-music -endel.

Denicola, Robert C. "Ex Machina: Copyright Protection for computer-generated works." Rutgers University Law Review 69 (2016): 251-287.

"Endel to release 20 algorithm- powered albums to help you sleep, focus $\&$ relax." Accessed March 27, 2020. https://endel.io/presskit/Endel-PressRelease-20MusicAlbums.pdf.

Flisak, Damian. "Czy robotowi przysługują prawa autorskie? Wywiad z dr Damianem Flisakiem.” Interview by Magdalena Miernik, 2017. Accessed 
August 27, 2020. https://lookreatywni.pl/baza-wiedzy/czy-sztuczna -inteligencja-zmieni-prawo-autorskie-wywiad-z-dr-damianem-flisakiem/.

Flisak, Damian. "Ustawa o prawie autorskim i prawach pokrewnych, Komentarz do art. 74." In Prawo autorskie i prawa pokrewne. Komentarz, edited by Damian Flisak, argument 7. Warsaw: Wolters Kluwer - LEX, 2015.

Flisak, Damian. "Ustawa o prawie autorskim i prawach pokrewnych. Komentarz do art. 11." In Prawo autorskie i prawa pokrewne. Komentarz, edited by Damian Flisak, argument 7. Warsaw: Wolters Kluwer - LEX, 2015.

Flisak, Damian, and Ireneusz Matusiak. "Ab homine Auctore Ad Robotum Auctorum." In Opus auctorem laudat. Ksiega jubileuszowa dedykowana Profesor Monice Czajkowskiej-Dąbrowskiej, edited by Krystyna Szczepanowska-Kozłowska, Ireneusz Matusiak, and Łukasz Żelechowski, 73-96. Warsaw: Wolters Kluwer, 2019.

Ginsburg, Jane C. "The Author's Place in the Future of Copyright." Proceedings of the American Philosophical Society 153, no. 2 (2009): 147-159.

Grubow, Jared Vasconcellos. "O.K. Computer: The Devolution of Human Creativity and Granting Musical Copyrights to Artificially Intelligent Joint Authors." Cardozo Law Reviev 40, no. 1 (2018): 387-424.

Hughes, Jim. The Key Roles of AI Engineers. 2019. Accessed August 27, 2020. https://engineeringmanagementinstitute.org/key-roles-ai-engineers.

Jankowska, Marlena. "Ustawa o prawie autorskim i prawach pokrewnych. Komentarz do art. 11.” In Prawo autorskie i prawa pokrewne. Komentarz, edited by Piotr Ślęzak, 1-7. Warsaw: C.H. Beck - Legalis, 2017.

Jankowska, Marlena. "Ustawa o prawie autorskim i prawach pokrewnych. Komentarz do art. 15." In Prawo autorskie i prawa pokrewne. Komentarz, edited by Piotr Ślęzak, 1-2. Warsaw: C.H. Beck - Legalis, 2017.

Kasperska, Anna. "Problemy zastosowania sztucznych sieci neuronalnych w praktyce prawniczej." Przeglad Prawa Publicznego, no. 11 (2017): 25-32.

Kubasiewicz, Magdalena. "Czym jest machine learning - technologia, która rewolucjonizuje świat?.” 2020. Accessed March 20, 2020. https://www.intellect.pl/blog/ machine-learning-co-to/?PageSpeed=noscript.

Lucas, André, Henri-Jacques Lusac, and Agnès Lucas-Schloetter. Traité de la propriété littéraire et artistique, 4th ed. Paris: Lexis Nexis, 2012.

Machała, Wojciech. "Ustawa o prawie autorskim i prawach pokrewnych. Komentarz do art. 74." In Prawo autorskie i prawa pokrewne. Komentarz, edited by Rafał Sarbiński. Warsaw: Wolters Kluwer - LEX, 2019.

Machała, Wojciech. "Prawo autorskie i prawa pokrewne. Komentarz do art. 11." In Prawo autorskie i prawa pokrewne. Komentarz, edited by Rafał Sarbiński. Warsaw: Wolters Kluwer - LEX, 2019. 
"Mission Intelligence Artificielle Et Culture." Conseil Supérieur De La Propriété Littéraire Et Artistique, 2020. Accessed May 08, 2020. https://www.wipo.int/ export/sites/www/aboutip/en/artificial_intelligence/call_for_comments/pdf/ ms_france_cspla_fr.pdf.

Müller, Vincent C., and Nick Bostrom. "Future Progress in Artificial Intelligence: A Survey of Expert Opinion." In Fundamental Issues of Artificial Intelligence, edited by Vincent C. Müller, 1-19. Berlin: Synthese Library, Springer, 2014. Accessed February 20, 2021. https://www.nickbostrom.com/papers/ survey.pdf.

Pavlus, John. "Clever Machines Learn How to Be Curious." 2017. Accessed December 13, 2019. https://www.quantamagazine.org/clever-machines-learn-how-to -be-curious-20170919/.

Ritterman, Stefan. Komentarz do ustawy o prawie autorskim. Cracow: W.L. Anczyca i Spółki, 1937.

Ryan, Mark. "Ada Lovelace, her Objection, Turing Tests and Universal Computing." 2019. Accessed August 04, 2020. https://medium.com/swlh/ada-lovelace -her-objection-e189717bd262.

Sokołowska, Dorota. "Utwory zbiorowe w prawie autorskim." Zeszyty Naukowe Uniwersytetu Jagiellońskiego. Prace z Prawa Wtasności Intelektualnej, no. 1 (2001).

Treppoz, Eduard, Alix Capely, Marie-Elvire De Moro-Giafferri, Boriana Guimberteau, Stéphanie Zeller, Sophie Micallef, Olivia Klimis, and Annabelle Divoy. "Droit d'auteur sur les œuvres générées artificiellement." AIPPI, Question 15. Accessed August 31, 2020. https://www.aippi.fr/upload/2019\%20 Londres/DROIT_DAUTEUR_Rapport_definitif.pdf.

Yanisky-Ravid, Shlomit. "Generating Rembrandt: Artificial Intelligence, Copyright and Accountability in the 3A Era: The Human-like Authors are already here: A New Model." Michigan State Law Review, no. 4 (2017): 659-726.

Wang, Amy X. "Warner Music Group Signs an Algorithm to a Record Deal." 2019. Accessed August 31, 2020. https:/www.rollingstone.com/pro/news/ warner-music-group-endel-algorithm-record-deal-811327/.

Wagner, James. "Rise of the Artificial Intelligence Author." Advocate 75, no.4 (2017): 527-534.

WIPO Technology Trends 2019 Artificial Intelligence, World Intellectual Property Organization, Geneva 2019. 